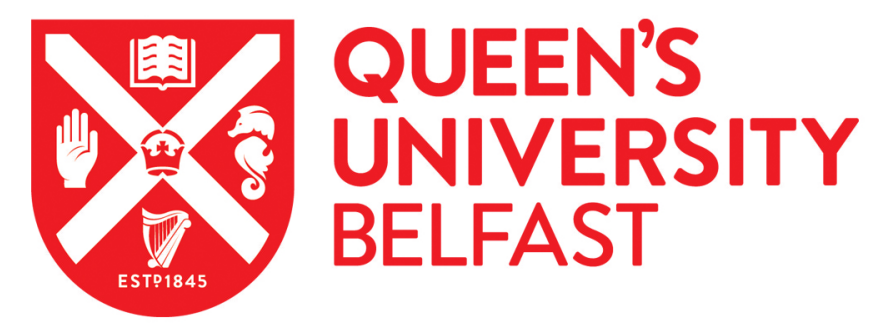

\title{
Further isotopic evidence for seaweed-eating sheep from Neolithic Orkney
}

Schulting, R. J., Vaiglova, P., Crozier, R., \& Reimer, P. J. (2017). Further isotopic evidence for seaweed-eating sheep from Neolithic Orkney. Journal of Archaeological Science Reports, 11, 463-470.

https://doi.org/10.1016/j.jasrep.2016.12.017

Published in:

Journal of Archaeological Science Reports

Document Version:

Peer reviewed version

Queen's University Belfast - Research Portal:

Link to publication record in Queen's University Belfast Research Portal

Publisher rights

(c) Elsevier Ltd. 2017

This manuscript version is made available under the CC-BY-NC-ND 4.0 license http://creativecommons.org/licenses/by-nc-nd/4.0/,which permits distribution and reproduction for non-commercial purposes, provided the author and source are cited.

\section{General rights}

Copyright for the publications made accessible via the Queen's University Belfast Research Portal is retained by the author(s) and / or other copyright owners and it is a condition of accessing these publications that users recognise and abide by the legal requirements associated with these rights.

Take down policy

The Research Portal is Queen's institutional repository that provides access to Queen's research output. Every effort has been made to ensure that content in the Research Portal does not infringe any person's rights, or applicable UK laws. If you discover content in the Research Portal that you believe breaches copyright or violates any law, please contact openaccess@qub.ac.uk. 

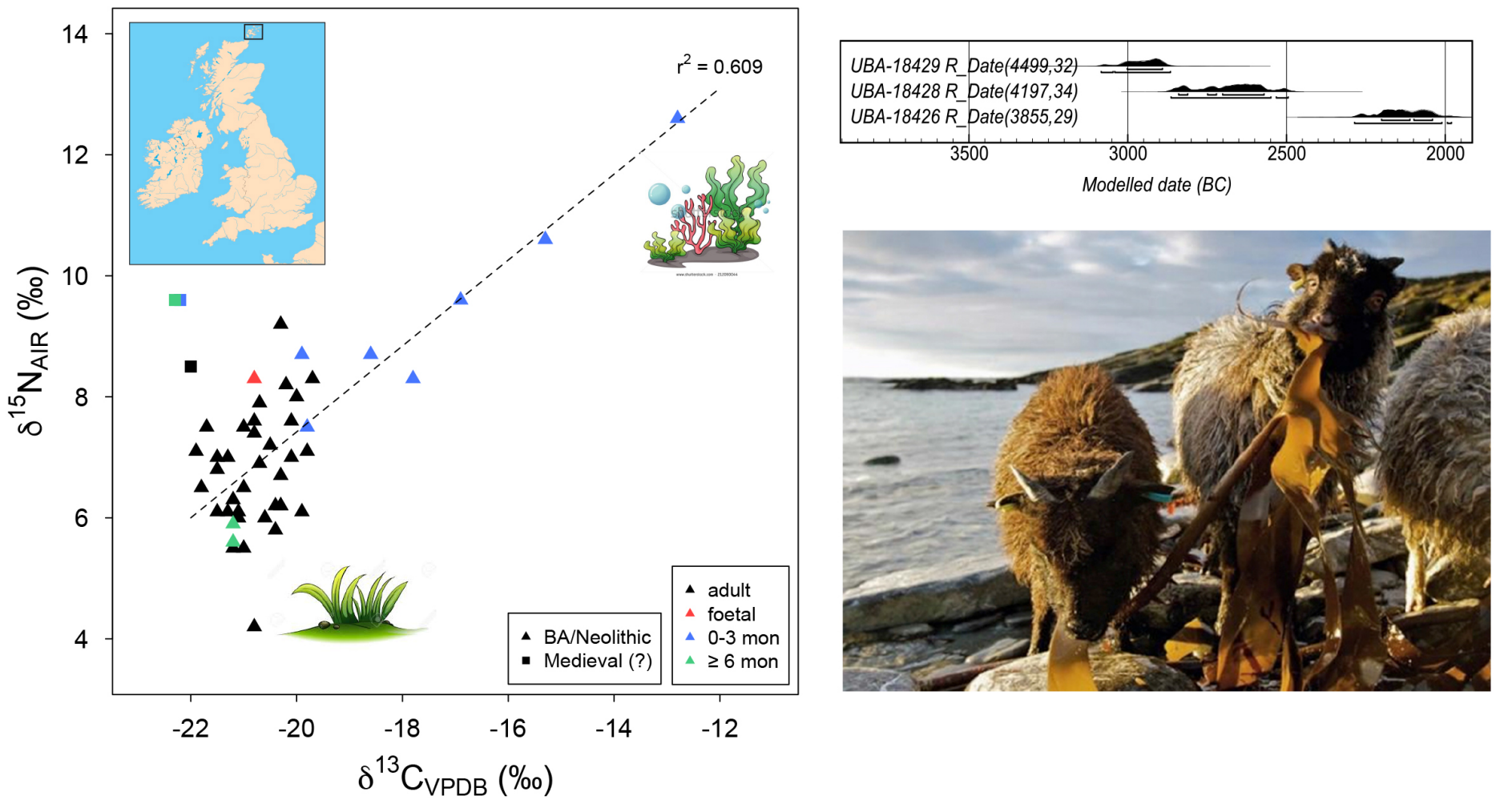


\section{Further isotopic evidence for seaweed-eating sheep from Neolithic Orkney}

Rick J. Schulting ${ }^{a}$ * Petra Vaiglova ${ }^{a, b}$ Rebecca Crozier ${ }^{\mathrm{c}, \mathrm{d}}$

Paula J. Reimer ${ }^{\mathrm{c}}$

${ }^{a}$ Research Laboratory for Archaeology and the History of Art, Dyson Perrins Building, South Parks Road, School of Archaeology, University of Oxford, Oxford, OX1 3QY, UK rick.schulting@arch.ox.ac.uk, petra.vaiglova@rlaha.ox.ac.uk

${ }^{\mathrm{b}}$ Wiener Laboratory for Archaeological Science, American School of Classical Studies Athens, 54 Souidias street, Athens 106 76, Greece

${ }^{c}$ Centre for Climate, the Environment \& Chronology $\left({ }^{14} \mathrm{CHRONO}\right)$, School of Natural and Built Environment, Queen's University, Belfast, BT7 1NN, UK p.j.reimer@qub.ac.uk

${ }^{\mathrm{d}}$ Archaeological Studies Program, Univerisity of the Philippines (Diliman Campus) Quezon City, Manila, 1101, Philippines

cccrozier@upd.edu.ph

*corresponding author, rick.schulting@arch.ox.ac.uk

\section{Abstract}

The antiquity of the practice of grazing on and/or foddering with seaweed is of interest in terms of understanding animal management practices in northwest Europe, where provision had to be made for overwintering. Orkney holds a special place in this discussion, since the sheep of North Ronaldsay have been confined to the seashores since the early nineteenth century, and are entirely adapted to a diet consisting mainly of seaweeds. Here, we report the results of stable carbon and nitrogen isotope analysis of twenty-five faunal specimens from the Neolithic chambered tomb of Quanterness, Orkney. Three of the 12 sheep analysed show elevated $\delta^{13} \mathrm{C}$ values that can only be explained by the consumption of seaweed. Radiocarbon dates place two of the three animals in the Neolithic, coeval with the use of the monument for burial, while the third animal dates to the Chalcolithic/Early Bronze Age. The findings are placed into the wider context of previous isotopic analyses of domestic fauna from prehistoric Orkney. A disjoint is noted between the results for bone collagen - where seaweed consumption seems to relate to the pre-natal period, since all the animals with high $\delta^{13} \mathrm{C}$ values are less than ca. three months of age - and previous studies using high-resolution sequential enamel measurements, which suggest a repeated pattern of winter consumption of seaweed in older animals.

Key words: stable carbon isotopes; Quanterness chambered tomb; palaeodietary modelling; marine reservoir effect 


\section{Introduction}

The extension of the Neolithic way of life to the fringes of northwest Europe posed new challenges, taking domesticated plants and animals far from their original habitats in the Near East. For the latter, the short growing season of browse and graze meant that provision must have been made for the overwintering of domestic stock (Amorosi et al. 1998). One resource available year-round along the coasts of northwest Europe is seaweed (e.g., Palmaria palmata, Fucus sp., Laminaria spp.). Historically, there is abundant evidence for the use of this resource, usually in dried form, as feed for both cattle and sheep (Chapman and Chapman 1980; Fenton 1978; Hallson 1964; Indergaard and Minsaas 1992; Kelly 1997; Makkar et al. 2016; Martin 1703). Without doubt the most dramatic evidence for this practice comes from North Ronaldsay in Orkney, where a sea-wall was built around the entire island's circumference in the early $19^{\text {th }}$ century to confine sheep to the seashore for most of the year (Fenton 1978; Hansen et al. 2003). Thus the question arises as to when this practice first emerged. The fact that consumption of seaweed leaves a distinct signal in the animals' stable carbon $\left(\delta^{13} \mathrm{C}\right)$ and oxygen $\left(\delta^{18} \mathrm{O}\right)$ isotope signatures - effectively making them appear isotopically similar to marine organisms (Ambers 1990) - provides the opportunity to explore this question with zooarchaeological remains. A small number of cases of sheep consuming seaweed in Orkney during the Neolithic have been previously identified using this method (Balasse et al. 2005; 2006; 2009; Balasse and Tresset 2009; Schulting et al. 2004; Schulting and Richards 2009). Here, we provide new evidence from the results of a programme of stable carbon $\left(\delta^{13} \mathrm{C}\right)$ and nitrogen $\left(\delta^{15} \mathrm{~N}\right)$ isotope analysis and accelerator mass spectrometry (AMS) radiocarbon dating of a faunal assemblage from the Middle-Late Neolithic chambered tomb of Quanterness, Mainland, Orkney.

\section{Overview of stable carbon and nitrogen isotope analysis}

Measurements of bone collagen stable carbon $\left(\delta^{13} \mathrm{C}\right)$ and nitrogen $\left(\delta^{15} \mathrm{~N}\right)$ values are frequently used in archaeology to investigate the major sources of dietary protein (Ambrose and Norr 1993; Lee-Thorp 2008). The values obtained via isotope ratio mass spectrometry (IRMS) provide a relatively long-term average of primarily protein intake, though the exact length of time represented will depend on the rate of remodeling of the 
81 sampled bone, but will always be more rapid in young, growing animals. The ratios of stable $\mathrm{C}$ and $\mathrm{N}$ isotopes incorporated into animal tissues are driven by the isotopic composition of major dietary sources. Marine organisms, including seaweed, shellfish, fish and sea mammals, are enriched in ${ }^{13} \mathrm{C}$ relative to ${ }^{12} \mathrm{C}$ due to the fact that the ocean serves as a sink for the heavier isotope (Boutton 1991; Sharp 2007). As a result, organisms obtaining a significant proportion of their dietary protein from marine foods will exhibit higher $\delta^{13} \mathrm{C}$ values (ca. $-12 \pm 1 \%$ ) than those subsisting solely on $\mathrm{C}_{3}$ terrestrial foods, which provide lower values (ca. $-21 \pm 1 \%$ ) for bone collagen (Richards and Hedges 1999). The consumption of $\mathrm{C}_{4}$ plants such as maize and millet would result in even higher bone collagen values than the consumption of marine foods, but as no such plants were found in northwest Europe during the study period, they need not be considered here.

Stable nitrogen isotope ratios are used to investigate trophic levels. There is a variable but broadly predictable increase of ca. 3-5\% between dietary item and consumer tissue for each step in the food chain (Ambrose 2000; Caut et al. 2009; Hedges and Reynard 2007; Schoeninger and DeNiro 1984). This range is generally cited for human consumers, and may be towards its lower end for most herbivores. The comparable effect in $\delta^{13} \mathrm{C}$ is considerably smaller, about 1\%。 (Bocherens and Drucker 2003; LeeThorp et al. 1989). The ocean is also enriched in ${ }^{15} \mathrm{~N}$ relative to atmospheric $\mathrm{N}_{2}$ (defined as $0 \%$ ), the latter serving as the ultimate source of nitrogen for terrestrial plants (Peterson and Fry 1987). Thus marine plants will generally have higher $\delta^{15} \mathrm{~N}$ values than most temperate terrestrial plants under natural conditions (i.e., in the absence of anthropogenic input). Furthermore, because marine food webs are considerably more complex (i.e., involve more steps) than terrestrial mammalian food webs, there is scope for much greater trophic level enrichment, such that high-level marine carnivores can exhibit collagen $\delta^{15} \mathrm{~N}$ values of $+16 \%$ or more (Schoeninger and DeNiro 1984). Other factors can also result in ${ }^{15} \mathrm{~N}$ enrichment, most notably aridity, but this can safely be excluded from discussions pertaining to Orkney.

110

\section{3. Materials and Methods}


112 The Quanterness chambered tomb is located near the east-central coast of Mainland

113 Orkney, northern Scotland (Figure 1). It serves as one of the two type-sites for the

114 Quanterness-Quoyness type of passage tomb (also known as the Maes-Howe type).

115 Excavated by Colin Renfrew in the 1970s (Renfrew 1979), the site yielded a large

116 human skeletal assemblage (Crozier 2012), as well as ceramic, lithic and faunal

117 remains. A recent dating programme focusing on the human remains placed the use of

118 the monument for burial in the second half of the fourth millennium $\mathrm{BC}$, continuing into

119 the first quarter of the third millennium (Schulting et al. 2010). The original dating

120 programme also identified one example (Pit $\mathrm{C}$ ) of deposition of human remains in the

121 third quarter of the third millennium BC (Renfrew 1979).

123 For this study, twenty-five faunal bone samples from the Quanterness assemblage were 124 selected for $\delta^{13} \mathrm{C}$ and $\delta^{15} \mathrm{~N}$ analysis. The samples included domestic sheep (Ovis aries, $125 \mathrm{n}=14$, all left humeri; 1 foetal, 8 juveniles, 1 adolescent, 4 adults), domestic cattle (Bos

126 Taurus, $\mathrm{n}=6$, pelvae and ribs; 3 perinatal, 3 adults), domestic pig (Sus scrofa, $\mathrm{n}=3$,

127 ulnae; 1 infant, 1 juvenile, 1 adult), dog (Canis domesticus, $\mathrm{n}=1$, right femur; adult) and

128 red deer (Cervus elaphus, $\mathrm{n}=1$, left humerus; adolescent). The identification of the

129 sampled humeri as sheep rather than goat is not based on their morphology (though 130 this is possible - see Zeder and Lapham 2010), but rather on the scarcity of identified 131 goat remains in Neolithic and Bronze Age Orkney overall. They will be referred to here 132 as 'sheep'; while there is a possibility that some are goat, this does not impact on the 133 larger discussion.

135 Figure 1. Map of Orkney showing locations mentioned in the text.

137 The sheep/goats (henceforth 'sheep') were aged using standards in Moran and 138 O'Connor (1994) and Popkin et al. (2012). One complete but very small humerus 139 (greatest length $=35.2 \mathrm{~mm}$ ) is from a foetal lamb far from full term (McDonald et al. 140 1977). Six animals are aged between birth and ca. 3 months based on the lengths of 141 (66-70mm) for three complete humeri, and a comparison of maximum breadth of these 142 specimens against the three incomplete elements. Three further humeri were in the 143 process of fusing distally, placing them at $\geq 6$ months. Finally, four animals are classed 
144 as adults based primarily on their size, confirmed by the fully fused proximal humerus in

145 the single complete specimen (>36 months).

147 Collagen was extracted from the samples following a modified Longin procedure

148 (Longin 1971; Richards and Hedges 1999). Measurements were made in duplicate on a

149 SerCon 'Callisto' continuous flow IRMS coupled to an elemental analyser at the

150 Research Laboratory for Archaeology and the History of Art, University of Oxford. An

151 alanine standard was used to correct for machine drift and calculate the measurement

152 precision $(1 \sigma)$ at $0.2 \%$ for $\delta^{13} \mathrm{C}$ and $\pm 0.3 \%$ for $\delta^{15} \mathrm{~N} . \delta^{13} \mathrm{C}$ and $\delta^{15} \mathrm{~N}$ are reported as per

153 mil (\%) relative to the international standards VPDB and AIR, respectively. C:N values

154 are reported as atomic ratios and serve as a check on collagen preservation (cf DeNiro

155 1985).

156

157 AMS radiocarbon dating was undertaken at the ${ }^{14} \mathrm{CHRONO}$ laboratory at Queen's

158 University Belfast. The sample ${ }^{14} \mathrm{C} /{ }^{12} \mathrm{C}$ ratio was background corrected and normalised

159 to the HOXII standard (SRM 4990C; National Institute of Standards and Technology)

160 and corrected for isotopic fractionation using the AMS-measured $\delta^{13} \mathrm{C}$ to account for

161 both natural and machine fractionation. The ${ }^{14} \mathrm{C}$ age and associated error were

162 calculated using the Libby half-life (5568 years) following the conventions of Stuiver and

163 Polach (1977). Nine samples were selected, targeting all the domestic species

164 represented at Quanterness, as well as one of the small number of red deer elements.

165 The main focus, however, was on sheep, since firstly, this taxon dominates the faunal

166 assemblage (Clutton-Brock 1979), and secondly, the $\delta^{13} \mathrm{C}$ results highlighted

167 considerable variability, and the sources of this variation were of particular interest. All

168 calibrated dates are reported at $95.4 \%$ confidence.

169

\section{3. Results}

171 The faunal stable isotope results from Quanterness are provided in Table 1 and plotted

172 in Figure 2. All samples passed collagen quality criteria including collagen yields and

173 C:N ratios (Ambrose 1990; DeNiro 1985; van Klinken 1999).

174

\begin{tabular}{|l|c|c|c|c|r|r|r|}
\hline Cat. No. & Species, Latin name & Species & Element & Age & $\delta^{13} C$ & $\delta^{15} N$ & $C: N$ \\
\hline 3074.22 & Ovis aries & sheep & L humerus & foetal & -20.8 & 8.3 & 3.3 \\
\hline
\end{tabular}




\begin{tabular}{|c|c|c|c|c|c|c|c|}
\hline 2491.04 & Ovis aries & sheep & L humerus & $0-3$ mon & -17.8 & 8.3 & 3.3 \\
\hline 4084.48 & Ovis aries & sheep & L humerus & $0-3$ mon & -19.8 & 7.5 & 3.3 \\
\hline 146.07 & Ovis aries & sheep & L humerus & $0-3$ mon & -18.6 & 8.7 & 3.3 \\
\hline 4084.2 & Ovis aries & sheep & L humerus & $0-3$ mon & -16.9 & 9.6 & 3.3 \\
\hline 3072.03 & Ovis aries & sheep & L humerus & $0-3$ mon & -19.9 & 8.7 & 3.2 \\
\hline 4029.07 & Ovis aries & sheep & L humerus & $0-3$ mon & -22.2 & 9.6 & 3.3 \\
\hline 4081.80 & Ovis aries & sheep & L humerus & ca. 6 mon & -22.3 & 9.6 & 3.2 \\
\hline 2416.03 & Ovis aries & sheep & L humerus & $>6$ mon & -21.2 & 5.9 & 3.3 \\
\hline 4570.02 & Ovis aries & sheep & L humerus & $>6$ mon & -21.2 & 5.6 & 3.3 \\
\hline 1328.02 & Ovis aries & sheep & L humerus & adult & -20.4 & 5.8 & 3.3 \\
\hline 249.11 & Ovis aries & sheep & L humerus & adult & -20.7 & 6.9 & 3.3 \\
\hline 2584.02 & Ovis aries & sheep & L humerus & adult & -21.0 & 5.5 & 3.3 \\
\hline 2361 & Ovis aries & sheep & L humerus & adult & -22.0 & 8.5 & 3.2 \\
\hline 803.2 & Bos taurus & cattle & innominate & perinatal & -21.7 & 6.6 & 3.4 \\
\hline 1258.03 & Bos taurus & cattle & innominate & perinatal & -21.7 & 5.2 & 3.3 \\
\hline 284 & Bos taurus & cattle & innominate & perinatal & -21.0 & 6.4 & 3.3 \\
\hline 4610 & Bos taurus & cattle & rib & adult & -21.4 & 5.4 & 3.2 \\
\hline 90.01 & Bos taurus & cattle & rib & adult & -21.5 & 5.1 & 3.3 \\
\hline 1050 & Bos taurus & cattle & rib & adult & -21.6 & 5.4 & 3.3 \\
\hline $4500.04 ?$ & Sus domesticus & pig & ulna & juvenile & -22.1 & 6.7 & 3.3 \\
\hline 5004.11 & Sus domesticus & pig & ulna & adult & -20.4 & 8.2 & 3.2 \\
\hline 4580.16 & Sus domesticus & pig & ulna & infant & -21.8 & 8.3 & 3.3 \\
\hline 4526.01 & Canis domesticus & dog & R femur & adult & -20.6 & 9.1 & 3.2 \\
\hline 1345.04 & Cervus elaphus & red deer & L humerus & adol & -20.9 & 5.3 & 3.3 \\
\hline
\end{tabular}

Table 1. Quanterness fauna sample details and results of $\delta^{13} \mathrm{C}$ and $\delta^{15} \mathrm{~N}$ analysis.

178 The six cattle values cluster tightly at $-21.5 \pm 0.3 \%$ and $5.7 \pm 0.6 \%$ ofor $\delta^{13} \mathrm{C}$ and $\delta^{15} \mathrm{~N}$

179 values, respectively. The single red deer value is comparable (-20.9\%o, 5.3\%o). The

180 three pigs analysed exhibit similar $\delta^{13} \mathrm{C}$ values $(-21.4 \pm 0.9 \%$ ) but are significantly

181 elevated above cattle and deer in $\delta^{15} \mathrm{~N}(7.7 \pm 0.9 \%$ ), reflecting their more omnivorous

182 diets. The single domestic dog in the study yielded values of $-20.6 \%$ and $9.1 \%$ for $\delta^{13} \mathrm{C}$

183 and $\delta^{15} \mathrm{~N}$, respectively.

185 The range of $\delta^{13} \mathrm{C}$ values for sheep (-22.3 to $-16.9 \%$ ) is considerably wider than that 186 seen in the other species. However, as noted below, the lowest values may date to the 187 medieval period. More interesting are three of the juvenile sheep aged 0-3 months 188 occupying the higher end of the range: including the other two animals in this age class 189 (excluding the lowest value), this group averages $-18.6 \pm 1.3 \%$ ofor $\delta^{13} \mathrm{C}$ and $8.6 \pm 0.8 \%$ 。 190 for $\delta^{15} \mathrm{~N}$ values, compared to $-20.9 \pm 0.35 \%$ and $5.9 \pm 0.6 \%$ ofor the five animals older 191 than ca. six months (i.e., with fused distal epiphyses). The foetal sample is 192 indistinguishable from the adults in its $\delta^{13} \mathrm{C}$ value $(-20.8 \%$ o), as would be expected, but 193 has a high $\delta^{15} \mathrm{~N}$ value (8.3\%), considerably higher than seen in the adult animals. While 
194 this would be unexpected in humans, it has been previously observed in sheep, and

195 may relate to differing placental systems (Balasse 1999: Appendix II, and pers. comm.).

196 As expected, the young lambs (0-3 months) are also enriched in ${ }^{15} \mathrm{~N}$ compared to the

197 older lambs and adult sheep (Table 2).

198

199

200

Figure 2. Plot of faunal and human $\delta^{13} \mathrm{C}$ and $\delta^{15} \mathrm{~N}$ results from Quanterness (human data from Schulting et al. 2010).

201

202

203

204

205

206

207

\begin{tabular}{|c|c|c|c|c|c|}
\hline Species & $\delta^{13} C$ & \pm & $\delta^{15} N$ & \pm & $n$ \\
\hline \multicolumn{6}{|l|}{ sheep } \\
\hline \begin{tabular}{l|l} 
& all \\
\end{tabular} & -20.3 & 1.6 & 7.8 & 1.5 & 14 \\
\hline foetal & -20.8 & - & 8.3 & - & 1 \\
\hline $0-3$ mon & -18.6 & 1.3 & 8.6 & 0.8 & 5 \\
\hline$>6$ mon & -20.9 & 0.3 & 5.9 & 0.6 & 5 \\
\hline \begin{tabular}{l|l} 
& medieval? \\
\end{tabular} & -22.2 & 0.2 & 9.2 & 0.6 & 3 \\
\hline cattle & -21.5 & 0.3 & 5.7 & 0.6 & 6 \\
\hline \begin{tabular}{l|l} 
& all
\end{tabular} & -21.5 & 0.4 & 5.7 & 0.6 & 6 \\
\hline perinatal & -21.5 & 0.4 & 6.1 & 0.8 & 3 \\
\hline adult & -21.5 & 0.1 & 5.3 & 0.2 & 3 \\
\hline pig & -21.4 & 0.9 & 7.7 & 0.9 & 3 \\
\hline dog & -20.6 & - & 9.1 & - & 1 \\
\hline red deer & -20.9 & - & 5.3 & - & 1 \\
\hline
\end{tabular}

Table 2. Summary statistics for Quanterness faunal $\delta^{13} \mathrm{C}$ and $\delta^{15} \mathrm{~N}$ measurements. The sheep identified as likely of medieval date (see Table 3 ) are included in the total but treated separately in the age categories.

\begin{tabular}{|c|c|c|c|c|c|c|c|c|c|c|c|}
\hline Cat no. & Species & Age & Lab code & ${ }^{14} C_{\text {yrs }}$ & \pm & \multicolumn{2}{|c|}{ cal BC (95.4\%) } & $\delta^{13} C$ & $\delta^{15} N$ & $C: N$ & $\%$ mar \\
\hline 4084.2 & Ovis Aries & 0-3 mon & UBA-18429 & 4499 & 32 & 3084 & 2866 & -16.9 & 9.6 & 3.3 & 46 \\
\hline 146.07 & Ovis Aries & $0-3$ mon & UBA-18428 & 4197 & 34 & 2864 & 2495 & -18.6 & 8.7 & 3.3 & 27 \\
\hline 2491.04 & Ovis Aries & $0-3$ mon & UBA-18426 & 3855 & 29 & 2286 & 1981 & -17.8 & 8.3 & 3.3 & 36 \\
\hline 249.11 & Ovis Aries & adult & UBA-18425 & 3367 & 31 & 1632 & 1427 & -20.7 & 6.9 & 3.3 & 3 \\
\hline 4029.07 & Ovis Aries & 0-3 mon & UBA-18427 & 908 & 25 & \multicolumn{2}{|c|}{ AD 1168-1300 } & -22.2 & 9.6 & 3.3 & 0 \\
\hline 4580.16 & Sus domesticus & infant & UBA-18432 & 4302 & 37 & 3014 & 2880 & -21.8 & 8.3 & 3.3 & 0 \\
\hline 1345.04 & Cervus elaphus & adol. & UBA-18431 & 3785 & 28 & 2196 & 1939 & -20.9 & 5.3 & 3.3 & 1 \\
\hline 1258.03 & Bos taurus & perinatal & UBA-18433 & 3649 & 24 & 2009 & 1755 & -21.7 & 5.2 & 3.3 & 0 \\
\hline 4526.01 & $\begin{array}{l}\text { Canis } \\
\text { domesticus }\end{array}$ & adult & UBA-18430 & 3466 & 24 & 1743 & 1535 & -20.6 & 9.1 & 3.2 & 4 \\
\hline
\end{tabular}

209 Table 3. Results of ${ }^{14} \mathrm{C}$ dating. Mixed marine-terrestrial curves are used for the three

210 young sheep with significantly elevated $\delta^{13} \mathrm{C}$ values (Reimer et al. 2013).

212 The radiocarbon dating results range widely, from $4499 \pm 32$ BP (UBA-18429) to $908 \pm$

21325 BP (UBA-18427) (Table 3). Calibration of the dates for three young lambs - including

214 the earliest result in the series - is complicated by their elevated $\delta^{13} \mathrm{C}$ values suggesting 
215 that they consumed significant amounts of marine foods. The use of a mixed

216 marine/terrestrial curve is therefore required, with '\%marine' being calculated using a

217 simple linear extrapolation between marine and terrestrial bone collagen endmembers

218 of $-12 \%$ and $-21 \%$, respectively (Barrett and Richards 2004; Richards and Hedges

219 1999; Schulting and Richards 2009) (Table 2). The validity of these endmembers has

220 been repeatedly confirmed on studies of archaeological marine and terrestrial fauna

221 from western and northern Scotland (Charlton et al. 2016; Montgomery et al. 2013;

222 Mulville et al. 2009; 2013; Richards et al. 2006). The estimate is assumed to have an

223 uncertainty of $\pm 10 \%$, included in the model (OxCal 4.2). A local $\Delta \mathrm{R}$ of $48 \pm 47$ years has

224 been used, based on the four nearest datapoints in Calib's Marine Reservoir

225 Corrections Database (http://calib.qub.ac.uk/marine/). No correction has been applied

226 for cases in which the estimated '\%marine' is less than $5 \%$, since the contribution of any

227 marine protein is uncertain at best.

229 Once calibrated, three results fall within the early to mid-third millennium cal BC, 230 conventionally designated as Late Neolithic in a British context, although the first 231 century or so of the third millennium is probably better understood as culturally 'Middle

232 Neolithic' in the sense that passage tombs still featured prominently on the mortuary 233 landscape (Schulting et al. 2010). Three results fall within the late third to early second 234 millennium, towards the end of the Chalcolithic in one case and within the Early Bronze 235 Age in the other two. Two results lie within the mid- to late second millennium, on the 236 border between the Early and Middle Bronze Age. Finally, the latest determination 237 within the group is clearly an outlier, falling within the medieval or late Norse period, cal 238 AD 1168-1300. This particular sample, a young lamb, was selected as one of three 239 showing unusually low $\delta^{13} \mathrm{C}$ values, of $-22.0 \%$ or less (Table 1 ). On this basis we 240 suspect, though cannot demonstrate, that all three samples may be medieval in date.

242 Figure 3. OxCal 4.2 (Bronk Ramsey 2013) plot of calibrated faunal dates from 243 Quanterness (excluding UBA-18427, $908 \pm 25$ BP).

244

\section{Discussion}

2464.1 Implications for animal management 
247 Significantly elevated $\delta^{13} \mathrm{C}$ values for three of the 14 sheep analysed from Quanterness 248 indicate the consumption of seaweed (for a summary of $\delta^{13} \mathrm{C}$ measurements made on 249 seaweeds from across the UK, see Balasse et al. 2005: table 1). There are no other 250 possibilities for enriched ${ }^{13} \mathrm{C}$ resources on the archipelago at this time, nor is there any 251 issue with the identification of the skeletal elements (left humeri) selected for analysis: 252 they are definitely ovicaprids. Based on the linear extrapolation used to correct their 253 radiocarbon dates for the marine reservoir effect, it is estimated that these three lambs 254 obtained between ca. $27 \%$ and $46 \%$ of their dietary protein from seaweeds, albeit 255 indirectly since they would be too young to be grazing. The results join previous 256 research that has identified a small number of sheep from prehistoric sites on Orkney 257 with elevated $\delta^{13} \mathrm{C}$ values similarly indicating the consumption of seaweeds. Two 258 neonatal lambs from Holm of Papa Westray North (HPWN) are represented by measurements on bone collagen, initially identified through radiocarbon dating (Bronk Ramsey et al. 2002; Schulting et al. 2004), with one sample re-analysed specifically for palaeodietary reconstruction (Schulting and Richards 2009). One of these neonates yielded extremely elevated $\delta^{13} \mathrm{C}$ and $\delta^{15} \mathrm{~N}$ values of $-12.8 \%$ and $12.6 \%$, respectively.

263 Essentially, this can be considered a 100\% marine diet. However, given that this animal 264 did not survive past infancy, this diet may have been in extremis on the part of its 265 mother rather than the result of an intentional management strategy. One previously 266 suggested possibility is that this sheep was part of a feral flock - or even just a few 267 animals - abandoned on the islet, though this in itself may be seen as part of a 268 management strategy (Balasse and Tresset 2009; Schulting and Richards 2009: 72).

270 The animals showing high $\delta^{13} \mathrm{C}$ values also tend to be elevated in $\delta^{15} \mathrm{~N}$. While this may 271 partly reflect the predictable enrichment caused by the nursing effect (Jenkins et al. 272 2001), such high values must be related to the considerably ${ }^{15} \mathrm{~N}$-enriched content of 273 seaweeds compared to grasses (Caumette et al. 2007). This is supported by the strong 274 positive correlation between $\delta^{13} \mathrm{C}$ and $\delta^{15} \mathrm{~N}$ values $\left(r^{2}=0.767, p<0.001\right)$ seen in the 275 Quanterness sheep (excluding the three cases thought to be medieval). Extending this 276 analysis to include the sheep from HPWN and other Neolithic and Bronze Age sites on 277 Orkney (Jones and Mulville 2016) reduces the strength of correlation $\left(r^{2}=0.609, p<\right.$ 2780.001 ) but only because of the greater scatter at the low end of the scale for both 
elements (Figure 4). It is worth noting that, while the sheep/goat data presented by Jones and Mulville (2016: table 2) do not include any definite examples of seaweed consumption (average $-20.8 \pm 0.6 \%$, maximum $-19.7 \%$ o, $n=26$ ), three animals do have values above $-20 \%$. Moreover, there is a slight but significant positive correlation between $\delta^{13} \mathrm{C}$ and $\delta^{15} \mathrm{~N}$ values $\left(r^{2}=0.127, p=0.045\right)$, which may plausibly reflect some marine influence (cf. Richards and Hedges 1999). As Jones and Mulville (2012: 670; see also Jones et al. 2012) note, it is possible that this is the result of foreshore grazing on terrestrial plants enriched in ${ }^{13} \mathrm{C}$ and ${ }^{15} \mathrm{~N}$ due to salinity effects (Heaton 1987; Britton et al. 2008), rather than the consumption of seaweed. However, this cannot account for the more elevated values seen in the young animals from Quanterness and HPWN. The absence of comparably elevated $\delta^{13} \mathrm{C}$ values in the larger number of samples analysed by Jones and Mulville can be explained by their decision to focus only on mature animals, to avoid complications introduced by nursing effects (2012: 668). While entirely understandable, this creates ambiguity in the interpretation of the adult values, and could mask periods of significant consumption of marine resources.

Figure 4. Plot of bone collagen $\delta^{13} \mathrm{C}$ and $\delta^{15} \mathrm{~N}$ measurements on sheep/goat from Neolithic and Bronze Age Orkney (data: this paper; Jones and Mulville 2016; Schulting and Richards 2009). The three squares identify low values thought to be medieval intrusions, and are not included in the regression.

Orcadian Neolithic and Bronze Age cattle, by contrast, show no correlation between $\delta^{13} \mathrm{C}$ and $\delta^{15} \mathrm{~N}$ values $\left(r^{2}=0.059, p=0.158\right)$ (Figure 5$)$. This is consistent with results from tooth enamel carbonate studies on cattle that have found no evidence for seaweed consumption (Balasse et al. 2006; Towers et al. 2016), despite their social and economic importance on Orkney from the Neolithic onwards. This may reflect the more adaptable gut physiology of sheep, in particular their tolerance of the high levels of arsenic found in seaweeds (Caumette et al. 2007; Feldman et al. 2000). However, this cannot be the entire explanation, since supplementing cattle fodder with seaweed is well attested historically (Hallson 1964; Makkar et al. 2016; Martin 1703). Perhaps the greater value of cattle - and hence greater investment in them - meant that the bulk of 
312 Figure 5. Plot of bone collagen $\delta^{13} \mathrm{C}$ and $\delta^{15} \mathrm{~N}$ measurements of humans and fauna

313 from Neolithic and Bronze Age Orkney (data: this paper; Jones and Mulville 2016;

314 Schulting et al. 2010; Schulting and Richards 2009).

A number of other examples interpreted as indicative of seaweed consumption in Neolithic Orkney derive from sequential $\delta^{13} \mathrm{C}$ measurements of tooth enamel from Point of Cott and HPWN, dating to ca. 3000 cal BC (Barber 1997; Ritchie 2009) and hence being contemporary with the earliest results from Quanterness. This method has the distinct advantage of providing resolution on an intra-annual seasonal level through comparison with accompanying $\delta^{18} \mathrm{O}$ measurements (Balasse et al. 2005; 2006; 2009; Balasse and Tresset 2009). At Point of Cott, one of three sheep second molars analysed presented a peak indicating a significantly ${ }^{13} \mathrm{C}$-enriched diet for part of the tooth mineralization period (Balasse et al. 2009). By contrast, all 12 sheep molars (M2s and M3s, representing the first and second years of life, respectively - Milhaud and Nezit 1991) analysed from HPWN recorded peaks in $\delta^{13} \mathrm{C}$ values during the colder season as represented by lower $\delta^{18} \mathrm{O}$ values, though not as low as would be expected for animals drinking from terrestrial water sources in the winter (Figure 6a) (Balasse et al. 2006; Balasse and Tresset 2009). Balasse and colleagues reasonably inferred from this that the HPWN sheep consumed fresh seaweed on the seashore (and ingested the oceanic water contained therein), rather than being foddered in the winter with dried seaweed collected specifically for this purpose (a practice for which there are historical references). The high enamel $\delta^{13} \mathrm{C}$ values suggest that the winter diet consisted of approximately $45-70 \%$ seaweed (Balasse et al. 2006: 173), so that the animals must still have had access to terrestrial vegetation. By contrast, none of the 11 sheep molars analysed from the nearby settlement of Knap of Howar, dating to a few centuries earlier - to ca. 3600 cal BC - show enriched $\delta^{13} \mathrm{C}$ values (Figure 6b). As Balasse et al. (2006) note, this could place the origins of the practice of seaweed foddering on Orkney towards the end of the fourth millennium BC. The Quanterness data support the consumption of seaweed by sheep dating to the same time period, but in the absence of earlier animals from the site cannot shed further light on this issue.

Figure 6. Plot of sequential enamel $\delta^{13} \mathrm{C}$ and $\delta^{18} \mathrm{O}$ measurements on sheep third molars from a) Holm of Papa Westray North, and b) Knap of Howar (Balasse and Tresset 2009). 
347 The modern and historically attested lambing season on Orkney takes place relatively 348 late, from late April to May/June (Balasse et al. 2006). Given a five month gestation 349 period, the foetus would be developing in utero from November to birth from late April.

350 The scarcity of grass over the winter months would make this period suited to the use of 351 seaweed as alternative fodder. Assuming that this pattern is broadly comparable to that 352 in the mid-Holocene (and there is no reason to think otherwise, given the absence of 353 significant climate change in the intervening period), then lambing would most likely 354 take place on the newly revitalised spring pastures. This also seems more probable 355 from the point of view of the safety of the newborn lambs, which might be susceptible to 356 being swept out to sea in the intertidal zone. Indeed, this is the current and historically 357 documented practice on North Ronaldsay, with females being moved from the shore onto inland pastures for lambing (Fenton 1978; Hansen et al. 2003).

The proportion of seaweed in the diet of the animals at HPWN suggested by the enamel $\delta^{13} \mathrm{C}$ values (45-70\%) would be expected to result in bone collagen values for the newborn lambs of ca. $-14.7 \%$ to $-17.0 \%$. While we cannot assume similar animal management practices between the two sites, it can be noted that, while the observed values for lambs in the 0-3 month age class at Quanterness do retain a 'marine influence', they are lower than this, ranging from $-16.9 \%$ o to $-19.9 \%$. But, following on from the above discussion, newborn lambs would be nursing on milk produced by ewes feeding on new grass. Because of the rapid growth seen in the skeletons at this age, their bone collagen $\delta^{13} \mathrm{C}$ values would change relatively rapidly, so that after three months they might very well fall within the observed range. The few older lambs that have been measured show no influence of seaweed. It is surprising that both they and the adult animals show so little input into their bone collagen of the winters spent, by at least some animals, during the first and second years of life consuming significant amounts of seaweed, as indicated by the sequential enamel measurements on second and third molars from Point of Cott and HPWN. While we cannot guarantee that any of the same animals were measured in the enamel and the bone collagen studies, given that all 12 molars analysed at HPWN showed seasonal consumption of seaweed, we would expect to find more evidence of this in the collagen of older animals, though 
admittedly there are only two measurements on adult sheep currently available from the site (Schulting and Richards 2009). That it was not detected at Knap of Howar is not surprising, since the enamel results did not find any evidence for the practice there.

By contrast, bone collagen of modern adult sheep on North Ronaldsay, confined to the seashore for most of the year, have the expected high $\delta^{13} \mathrm{C}$ values averaging ca. $-13 \%$ 。 (Ambers 1990). While the adolescent and adult sheep from Quanterness do have significantly higher average $\delta^{13} \mathrm{C}$ values than the cattle from the site (-20.9\%。 vs. $21.5 \%$, Student's t-test, $t=3.18, p=0.011$ ), the difference is only $0.6 \%$. This is hard to reconcile, though of course the same animals are not being measured in the enamel and collagen studies, nor indeed are they from the same site, though they are approximately contemporary and in relatively close proximity to one another. (That measurements on enamel reflect whole diet while collagen measurements are biased towards dietary protein (Ambrose and Norr 1993) should not be an issue here, since seaweeds and grasses appear to have similar protein content and digestibility (Hansen et al. 1991)). Statistically significant differences of a similar order were identified between sheep/goat and cattle $\delta^{13} \mathrm{C}$ values by Jones and Mulville (2016: 668-669) for Neolithic, Bronze Age and Iron Age Orkney, as well as for the Bronze Age of the Western Isles (though not the Neolithic or the Iron Age). However, as noted above, this could relate in part to coastal grazing rather than episodic high seaweed consumption. Sequential enamel $\delta^{13} \mathrm{C}$ analyses of sheep and cattle from the Iron Age and Norse periods in Orkney have found no evidence for seaweed foddering (Mainland et al. 2016). Ambers (1990) also found no evidence for the practice in prehistoric Orkney, in a study using $\delta^{13} \mathrm{C}$ measurements on bone collagen.

Given that only very young animals show a distinct 'marine' $\delta^{13} \mathrm{C}$ signal, it is possible that foddering pregnant ewes with seaweed was in fact a last resort when terrestrial resources failed, so that young animals born when their mothers had been on this diet were more likely to die, and hence retain elevated $\delta^{13} \mathrm{C}$ values in their bone collagen. This is reminiscent of a recent study of sequential human dentine isotope measurements from a Neolithic site on the small island of West Voe, Shetland, showing that those individuals with periodic high use of marine resources were more likely to die 
young (Montgomery et al. 2013). In both cases the burial assemblage is intrinsically

411 biased by differential survivorship - the classic 'osteological paradox' (Wood et al.

412 1992).

\subsection{Implications for Neolithic human diet}

The evidence for seaweed consumption by pregnant ewes, seen most clearly in newborn lambs, raises questions regarding their impact on human diets. Essentially, a 'marine' isotopic signal could be introduced through the consumption of a terrestrial mammal. As discussed in Schulting and Richards (2009), this is an alternative explanation to the direct exploitation of marine resources for the slight elevation in the $\delta^{13} \mathrm{C}$ values observed in human bone collagen from the chambered tomb of HPWN. However, this slight elevation was being considered in comparison with the human results from Quanterness, where there seems to be no clearly detectable impact on $\delta^{13} \mathrm{C}$ values of the use of marine resources $(-20.6 \pm 0.3 \%$ ), whether direct or indirect (Figure 2). Following the discussion above, this is perhaps not surprising. Only a small number of very young lambs show significantly enriched carbon and nitrogen isotope values. Once on grass, which likely was the case from birth, their flesh values would very quickly become depleted in ${ }^{13} \mathrm{C}$, reflecting this dietary change. The bone collagen of adult sheep appears to show surprisingly little impact of seaweed consumption, though interpretation is complicated by the bone and tooth enamel analyses being conducted on different animals.

Another finding to emerge from this study is that the use of direct radiocarbon dating of at least a sample of faunal remains is essential in those cases where the contemporaneity of the faunal assemblage cannot be securely assigned to a phase on archaeological/stratigraphic grounds. This is highlighted here by the fact that only three of the nine determinations returned results coeval with the use of the chambered tomb for burial in the Late Neolithic. Despite the presence of intrusive fauna, it is interesting to note that the early dates include one of the three pigs represented in the study. Pigs are relatively rare in Orcadian Neolithic faunal assemblages, and this can be explained by the limited availability of natural habitat suited to their foraging preferences (i.e., woodland). Hence, they would likely need to be supplied with food at least some of 
which would be suitable for humans, and would thus be in competition (McCormick and

443 Buckland 2003: 91; Schulting 2013). A small number of pigs may have been fed on

444 domestic refuse and crop waste. Pigs can also be fed marine foods (seaweed, shellfish, 445 fish), but, surprisingly, there is no isotopic evidence for this in Orcadian prehistory. It is 446 not until the Iron Age that we see convincing evidence for this practice, not in Orkney, 447 but in the Western Isles (Jones and Mulville 2016: figure 13).

449 Three faunal samples can be placed within the Chalcolithic/Early Bronze Age, while 450 another two lie at the Early-Middle Bronze Age border. This chronology is considerably 451 more extended than that for the human remains (Schulting et al. 2010). What is less 452 clear is the nature of the deposition of the faunal remains post-dating the use of the 453 tomb for burial. The lack of other finds (e.g., pottery) dating to the Bronze Age suggests 454 that the deposition may not have been intentional, or at least not ritual, but rather that 455 animals sought shelter in the monument and died there naturally, or were disposed of 456 there by Bronze Age farmers. A re-examination of the fauna for butchery marks might 457 help in choosing between these alternatives, although the mixed nature of the deposits 458 means that an extensive programme of radiocabron dating would be required to identify 459 the Bronze Age component. Finally, one juvenile sheep dates to the medieval period, 460 known as the late Norse period on Orkney. The latter is particularly significant, since it is 461 one of a group of three animals with notably lower than average $\delta^{13} \mathrm{C}$ values at the site. 462 Assuming that the other two animals are also later intrusions, it is clear that using these 463 results for formal palaeodietary modelling of the human isotopic results could be highly 464 misleading. If it is confirmed that all three are late, a question is raised over why they 465 should be depleted in ${ }^{13} \mathrm{C}$ during this period.

\section{5. Conclusions}

468 The faunal $\delta^{13} \mathrm{C}$ and $\delta^{15} \mathrm{~N}$ data from Quanterness provide further evidence for the 469 consumption of seaweeds, probably by pregnant ewes, on Orkney from the late fourth 470 millennium BC, with additional cases in both the early and late third millennium, 471 extending the temporal range of this practice into the Chalcolithic. However, the extent 472 to which this was part of an ongoing, intentional management strategy remains unclear. 473 An alternative scenario is that the use of seaweed was a fallback strategy in years 
474 where insufficient terrestrial grasses were available to last the winter. Only a very

475 minimal increase in $\delta^{13} \mathrm{C}$ values can be found in the bone collagen of older lambs and

476 adult animals, so that little impact on human diets would be expected, consistent with

477 what has been observed in the previously published human results from Quanterness

478 (Schulting et al. 2010).

479

480 It is clear that further research is required to better understand the origins and

481 implications of the practice of seaweed foddering in northern Europe. Enamel studies

482 have indicated recurrent substantial consumption of seaweed in the winter by

483 adolescent and adult sheep, yet the impact on bone collagen is minimal. However,

484 these studies have rarely been joined up, and have been carried out on different

485 individuals often from different sites. Clearly there is scope for a more coordinated

486 effort, which could also include dental microwear analysis (e.g., Mainland et al. 2016),

487 which has been shown to be capable of distinguishing between seaweed and grass

488 grazing sheep (Mainland 2000). There is currently an impression that the practice did

489 not continue into later prehistory, suggesting that perhaps it was not particularly

490 successful as a management strategy, at least until revived in the nineteenth century on

491 North Ronaldsay. It should not be assumed that once a new farming practice appears, it

492 will continue to be used thereafter. Future research will need to focus on immature

493 animals and sequential sampling of both enamel and dentine.

494

495 Acknowledgements

496 Many thanks to Alison Sheridan and the National Museums Scotland for permission to

497 sample the Quanterness fauna and to Richard Sabin of the Natural History Museum,

498 London, for facilitating access to the collection, which was in temporary storage there.

499 Thanks also to Marie Balasse and an anonymous referee for their very useful feedback,

500 and to Marie Balasse for permission to cite her doctoral thesis and to reproduce a graph

501 of her stable isotope results. The wonderful photograph of a seaweed-eating sheep

502 from North Ronaldway in the graphical abstract is courtesy of the Orkney Sheep

503 Foundation. The research was supported by the Research Laboratory for Archaeology

504 and the History of Art, University of Oxford, and by the ${ }^{14} \mathrm{CHRONO}$ laboratory, Queen's 
University Belfast. The authors did not receive any specific grant from funding agencies in the public, commercial, or not-for-profit sectors.

\section{References}

Ambers, J.C., 1990. Identification of the use of marine plant material as animal fodder by stable isotope ratios, PACT 29, 251-258.

Ambrose, S.H., 1990. Preparation and characterization of bone and tooth collagen for isotopic analysis, J. Archaeol. Sci. 17, 431-451.

Ambrose, S.H., Norr, L., 1993. Experimental evidence for the relationship of the carbon isotope ratios of whole diet and dietary protein to those of bone collagen and carbonate, in: Lambert, J.B., Grupe, G. (Eds.), Prehistoric Human Bone: Archaeology at the Molecular Level, Springer-Verlag, New York, pp. 1-37.

Amorosi, T., Buckland, P., Edwards, K., Mainland, I., McGovern, T., Sadler, J., Skidmore, P., 1998. They did not live by grass alone: the politics and palaeoecology of animal fodder in the North Atlantic region, Env. Archaeol. 1, 41-54.

Balasse, M. 1999. De l'exploitation du lait au Néolithique moyen, en Europe tempérée. Examen des modalités de sevrage des bovins, par l'analyse isotopique des ossements archéologiques. Thèse de doctorat de l'Université Paris 6, Mémoires des Sciences de la Terre 99-26, Paris.

Balasse, M., Mainland, I.L., Richards, M.P., 2009. Stable isotope evidence for seasonal consumption of marine seaweed by modern and archaeological sheep in the Orkney archipelago (Scotland), Env. Archaeol. 14, 1-14.

Balasse, M. and Tresset, A. 2009. A key to the adaptation of Neolithic husbandry in the Orkneys: contribution of seaweed to the sheep diet at the Holm of Papa Westray, revealed through stable isotope analysis $\left(\delta^{13} \mathrm{C}\right.$ and $\left.\delta^{18} \mathrm{O}\right)$ of teeth, in: A. Ritchie (Ed.), On the Fringe of Neolithic Europe, Society of Antiquaries of Scotland, Edinburgh, pp. 74-82.

Balasse, M., Tresset, A., Ambrose, S.H., 2006. Stable isotope evidence $\left(\delta^{13} \mathrm{C}, \delta^{18} \mathrm{O}\right)$ for winter feeding on seaweed by Neolithic sheep of Scotland, J. Zool. 270, 170-176.

Balasse, M., Tresset, A., Dobney, K., Ambrose, S.H., 2005. The use of isotope ratios to test for seaweed eating in sheep, J. Zool. 266, 283-291.

Barber, J., 1997. The Excavation of a Stalled Cairn at the Point of Cott, Westray, Orkney, Scottish Trust for Archaeological Research, Edinburgh.

Barrett, J.H., Richards, M.P., 2004. Identity, gender, religion and economy: New isotope and radiocarbon evidence for marine resource intensification in early historic Orkney, Scotland, Euro. J. Archaeol. 7, 249-271. 
Bocherens, H., Drucker, D., 2003. Trophic level isotopic enrichments for carbon and nitrogen in collagen: case studies from recent and ancient terrestrial ecosystems, Int. J.

Boutton, T.W., 1991. Stable carbon isotope ratios of natural materials: II. Atmospheric, terrestrial, marine and freshwater environments, in: Coleman, D.C., Fry, B. (Eds.), Carbon Isotope Techniques, Academic Press, San Diego, pp. 173-185.

Britton, K., Müldner, G., Bell, M., 2008. Stable isotope evidence for salt-marsh grazing in the Bronze Age Severn Estuary, UK: implications for palaeodietary analysis at coastal sites, J. Archaeol. Sci. 35, 2111-2118.

Bronk Ramsey, C., OxCal 4.2, https://c14.arch.ox.ac.uk/, 2013.

Bronk Ramsey, C., Higham, T.F.G., Owen, D.C., Pike, A.W.G., Hedges, R.E.M., 2002. Radiocarbon dates from the Oxford AMS system: Archaeometry datelist 31, Archaeometry 44, 1-150.

Caumette, G., Ouypornkochagorn, S., Scrimgeour, C.M., Raab, A., Feldmann, J., 2007. Monitoring the arsenic and lodine exposure of seaweed-eating North Ronaldsay sheep from the gestational and suckling periods to adulthood by using horns as a dietary archive, Env. Sci. Technol. 41, 2673-2679.

Caut, S., Angulo, E., Courchamp, F., 2009. Variation in discrimination factors $(\Delta 15 \mathrm{~N}$ and $\triangle 13 C)$ : the effect of diet isotopic values and applications for diet reconstruction, J. Appl. Ecol. 46, 443-453.

Chapman, V.J., Chapman, D.J., 1980. Seaweeds and their Uses, 3rd ed., Chapman and Hall, London.

Clutton-Brock, J., 1979. Report on the mammalian remains other than rodents from Quanterness, in: Renfrew, C. (Ed.), Investigations in Orkney, Thames and Hudson, London, pp. 112-134.

Crozier, R., A taphonomic approach to the re-analysis of the human remains from the Neolithic chamber tomb of Quanterness, Orkney, Unpublished PhD thesis, Queen's University Belfast, 2012.

DeNiro, M.J., 1985. Post-mortem preservation and alteration of in vivo bone collagen isotope ratios in relation to palaeodietary reconstruction, Nature $317,806-809$.

Feldmann, J., John, K., Pengsprecha, P., 2000. Arsenic metabolism in seaweed-eating sheep from Northern Scotland, Fresenius J. Anal. Chem. 368, 116-121.

Fenton, A., 1978. The Northern Isles: Orkney and Shetland, John Donald, Edinburgh.

Hallsson, S.V., 1964. The uses of seaweed in Iceland, in: De Virville, D., Feldman, J. (Eds.), Proceedings of the Fourth International Seaweed Symposium, Pergamon Press, 
Oxford, pp. 398-405.

Hansen, H.R., Hector, B.L., Feldmann, J., 2003. A qualitative and quantitative study of the seaweed diet of North Ronaldsay sheep, Anim. Feed Sci. Technol. 105, 21-28.

Heaton, T.H.E., 1987. The ${ }^{15} \mathrm{~N} /{ }^{14} \mathrm{~N}$ ratios of plants in South Africa and Namibia: relationship to climate and coastal/saline environments, Oecol. 74, 236-246.

Hedges, R.E.M., Reynard, L.M., 2007. Nitrogen isotopes and the trophic level of humans in archaeology, J. Archaeol. Sci. 34, 1240-1251.

Indergaard, M., Minsaas, J., 1991. Animal and human nutrition, in: Guiry, M.D., Blunden, G. (Eds.), Seaweed Resources in Europe: Uses and Potential, Wiley, Chichester, pp. 21-64.

Jenkins, S.G., Partridge, S.T., Stephenson, T.R., Farley, S.D., Robbins, C.T., 2001. Nitrogen and carbon isotope fractionation between mothers, neonates, and nursing offspring, Oecol. 129, 336-341.

Jones, J.R., Mulville, J., 2016. Isotopic and zooarchaeological approaches towards understanding aquatic resource use in human economies and animal management in the prehistoric Scottish North Atlantic Islands, J. Archaeol. Sci. Rep. 6, 665-677.

Jones, J.R., Mulville, J., McGill, R.A.R., Evershed, R.P., 2012. Palaeoenvironmental modelling of $\delta 13 \mathrm{C}$ and $\delta 15 \mathrm{~N}$ values in the North Atlantic Islands: understanding past marine resource use, Rapid Commun. Mass Spectrom. 26, 2399-2406.

Kelly, F., 1997. Early Irish Farming, Dublin Institute for Advance Studies, Dublin.

Lee-Thorp, J., Sealy, J., van der Merwe, N.J., 1989. Stable carbon isotope ratio differences between bone collagen and bone apatite, and their relationship to diet, J. Archaeol. Sci. 16, 585-599.

Lee-Thorp, J.A., 2008. On isotopes and old bones, Archaeometry 50, 925-950.

Longin, R., 1971. New method of collagen extraction for radiocarbon dating, Nature 230, 241-242.

Mainland, I., Towers, J., Ewens, V., Davis, G., Batey, C., Card, N., Downes, J., 2016. Toiling with teeth: An integrated dental analysis of sheep and cattle dentition in Iron Age and Viking-Late Norse Orkney, J. Archaeol. Sci. Rep. 6, 837-855.

Mainland, I.L., 2000. A dental microwear study of seaweed-eating and grazing sheep from Orkney, Int. J. Osteoarchaeol. 10, 93-107.

Makkar, H.P.S., Tran, G., Valérie Heuzé, Giger-Reverdin, S., Lessire, M., Lebas, F., Ankers, P., 2016. Seaweeds for livestock diets: A review, Anim. Feed Sci. Technol. 212, 1-7. 
Martin, M., 1703. A Description of the Western Islands of Scotland Circa 1695, Andrew Bell, London.

McCormick, F., Buckland, P.C., 2003. The vertebrate fauna, in: Edwards, K.J., Ralston, I.B.M. (Eds.), Scotland After the Ice Age: Environment and Archaeology, 8000 BC - AD 1000, Edinburgh University Press, Edinburgh, pp. 83-103.

McDonald, I., Wenham, G., Robinson, J.J., 1977. Studies on reproduction in prolific ewes. 3. The development in size and shape of the foetal skeleton, J. Agr. Sci. 89, 373391.

658

659

660

661

662

663

664

665

666

667

668

669

670

671

672

673

674

675

676

677

678

679

680

681

682

683

684

685

686

687

688

689

690

691

692

693

694

Milhaud, G., Nezit, J., 1991. Molar development in sheep: morphology, radiography, microhardness, Rec. Méd. Vét. 167, 121-127.

Montgomery, J., Beaumont, J., Jay, M., Keefe, K., Gledhill, A.R., Cook, G.T., Dockrill, S.J., Melton, N.D., 2013. Strategic and sporadic marine consumption at the onset of the Neolithic: increasing temporal resolution in the isotope evidence, Antiq. 87, 1060-1072.

Moran, N.C., O'Connor, T.P., 1994. Age attribution in domestic sheep by skeletal and dental maturation: a pilot study of available sources, Int. J. Osteoarchaeol. 4, 267-285.

Popkin, P.R.W., Baker, P., Worley, F., Payne, S., Hammon, A., 2012. The Sheep Project (1): determining skeletal growth, timing of epiphyseal fusionand morphometric variation in unimproved Shetland sheep of known age, sex, castration status and nutrition, J. Archaeol. Sci. 39, 1775-1792.

Reimer, P.J., Bard, E., Bayliss, A., Beck, J.W., Blackwell, P.G., Bronk Ramsey, C., Buck, C.E., Cheng, H., Edwards, R.L., Friedrich, M., Grootes, P.M., Guilderson, T.P., Haflidason, H., Hajdas, I., Hatté, C., Heaton, T.J., Hoffmann, D.L., Hogg, A.G., Hughen, K.A., Kaiser, K.F., Kromer, B., Manning, S.W., Niu, M., Reimer, R.W., Richards, D.A., Scott, E.M., Southon, J.R., Staff, R.A., Turney, C.S.M., van der Plicht, J., 2013. IntCal13 and Marine13 Radiocarbon Age Calibration Curves 0-50,000 Years cal BP, Radiocarbon 55, 1869-1887.

Renfrew, C., 1979. The chambered cairn at Quanterness: the excavation, in: Renfrew, C. (Ed.), Investigations in Orkney, Thames and Hudson, London, pp. 44-72.

Richards, M.P., Hedges, R.E.M., 1999. Stable isotope evidence for similarities in the types of marine foods used by Late Mesolithic humans on the Atlantic coast of Europe, J. Archaeol. Sci. 26, 717-722.

Richards, M.P., Fuller, B.T. and Molleson, T.I. 2006. Stable isotope palaeodietary study of humans and fauna from the multi-period (Iron Age, Viking and Late Medieval) site of Newark Bay, Orkney, J. Archaeol. Sci. 33, 122-131.

Ritchie, A. (Ed.), 2009. On the Fringe of Neolithic Europe: Excavation of a Chambered Cairn on the Holm of Papa Westray, Orkney, Society of Antiquaries of Scotland, 
Edinburgh.

Schoeninger, M.J., DeNiro, M.J., 1984. Nitrogen and carbon isotopic composition of bone collagen from marine and terrestrial animals, Geochim. Cosmochim. Acta 48, 625639 .

Schulting, R.J., 2013. On the northwestern fringes: Earlier Neolithic subsistence in Britain and Ireland as seen through faunal remains and stable isotopes, in: Colledge, S., Conolly, J., Dobney, K., Manning, K., Shennan, S. (Eds.), The Origins and Spread of Stock-Keeping in the Near East and Europe, Left Coast Press, Walnut Creek, California, pp. 313-338.

Schulting, R.J., Richards, M.P., 2009. Radiocarbon dates and stable isotope values on human remains, in: Ritchie, A. (Ed.), On the Fringe of Neolithic Europe, Society of Antiquaries of Scotland, Edinburgh, pp. 67-74.

Schulting, R.J., Sheridan, A., Crozier, R., Murphy, E., 2010. Revisiting Quanterness: new AMS dates and stable isotope data from an Orcadian chamber tomb, Proc. Soc. Antiq. Scotland 140, 1-50.

Schulting, R.J., Tresset, A., Dupont, C., 2004. From harvesting the sea to stock rearing along the Atlantic façade of north-west Europe, Env. Archaeol. 9, 143-154.

Sharp, Z., 2007. Principles of Stable Isotope Geochemistry, Pearson Prentice Hall, Upper Saddle River, NJ.

Stuiver, M., Polach, H.A., 1977. Reporting of ${ }^{14} \mathrm{C}$ data, Radiocarbon 19, 355-363.

Towers, J., Mainland, I., Montgomery, J., Bond, J., 2016 (early view). Calving seasonality at Pool, Orkney during the first millennium $A D$ : an investigation using intratooth isotope ratio analysis of cattle molar enamel, Env. Archaeol. doi: 10.1080/14614103.2015.1116214

van Klinken, G.J., 1999. Bone collagen quality indicators for palaeodietary and radiocarbon measurements, J. Archaeol. Sci. 26, 687-695.

Wood, J.W., Milner, G.R., Harpending, H.C., Weiss, K.M., 1992. The osteological paradox: Problems of inferring prehistoric health from skeletal samples, Curr. Anthropol. 33, 343-370.

Zeder, M.A., Lapham, H.A., 2010. Assessing the reliability of criteria used to identify postcranial bones in sheep, Ovis, and goats, Capra, J. Archaeol. Sci. 37, 2887-2905. 


\section{Figures and Tables}

Figure 1. Map of Orkney showing locations mentioned in the text.

Figure 2. Plot of $\delta^{13} \mathrm{C}$ and $\delta^{15} \mathrm{~N}$ results from Quanterness

Figure 3. OxCal 4.2 (Bronk Ramsey 2013) plot of calibrated faunal dates from Quanterness (excluding UBA-18427, $908 \pm 25$ BP).

Figure 4. Plot of bone collagen $\delta^{13} \mathrm{C}$ and $\delta^{15} \mathrm{~N}$ measurements on sheep/goat from Neolithic and Bronze Age Orkney (data: this paper; Jones and Mulville 2016; Schulting and Richards 2009). The three squares identify low values thought to be medieval intrusions, and are not included in the regression.

Figure 5. Plot of bone collagen $\delta^{13} \mathrm{C}$ and $\delta^{15} \mathrm{~N}$ measurements on humans and fauna from Neolithic and Bronze Age Orkney (data: this paper; Jones and Mulville 2016; Schulting et al. 2010; Schulting and Richards 2009).

Figure 6. Plot of sequential enamel $\delta^{13} \mathrm{C}$ and $\delta^{18} \mathrm{O}$ measurements on sheep third molars from a) Holm of Papa Westray North, and b) Knap of Howar (Balasse and Tresset 2009).

Table 1. Quanterness fauna sample details and results of $\delta^{13} \mathrm{C}$ and $\delta^{15} \mathrm{~N}$ analysis.

Table 2. Summary statistics for Quanterness fauna $\delta^{13} \mathrm{C}$ and $\delta^{15} \mathrm{~N}$ results.

Table 3. Results of ${ }^{14} \mathrm{C}$ dating. Mixed marine-terrestrial curves are used for the three juvenile sheep with significantly enriched ${ }^{13} \mathrm{C}$ (Reimer et al. 2013). 
North Ronaldsay

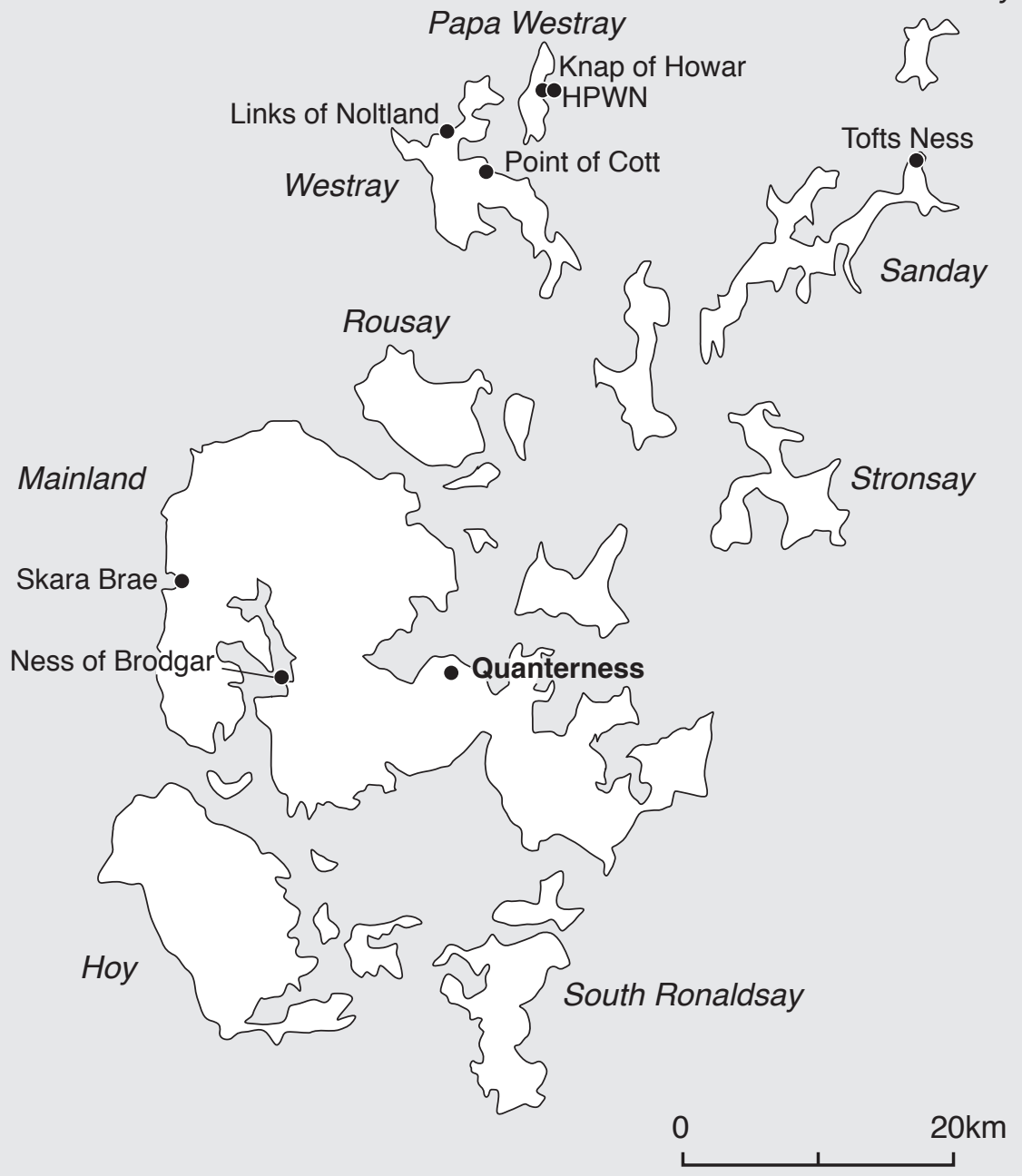




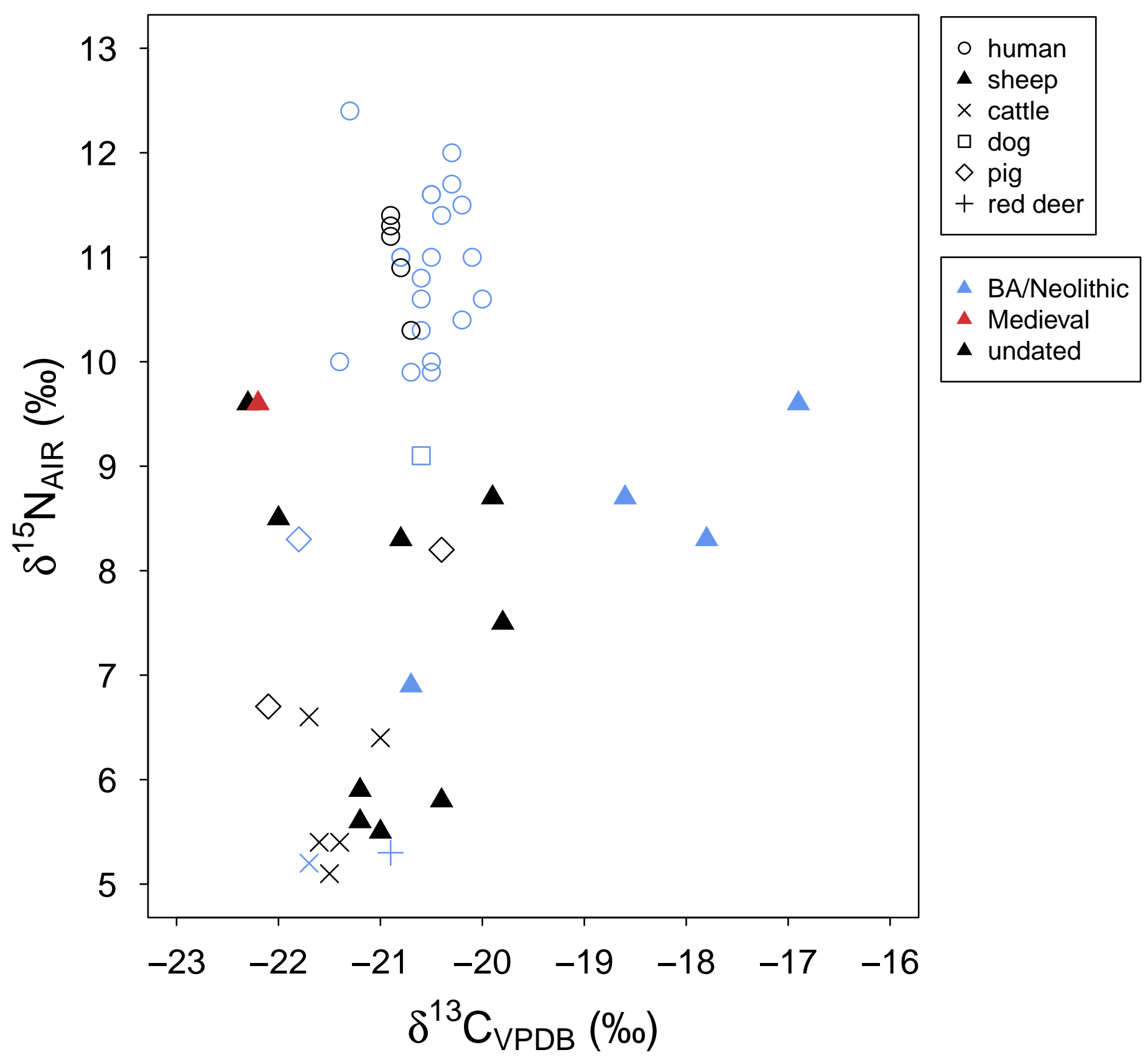




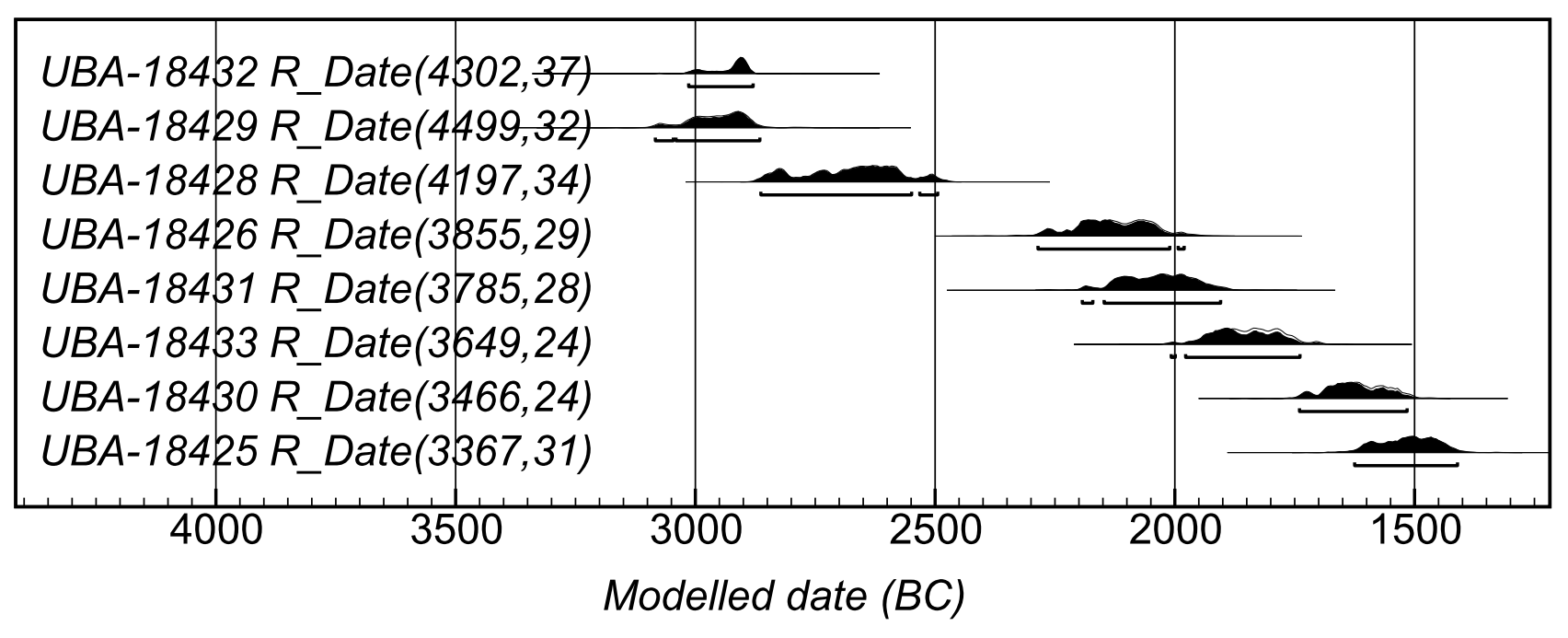




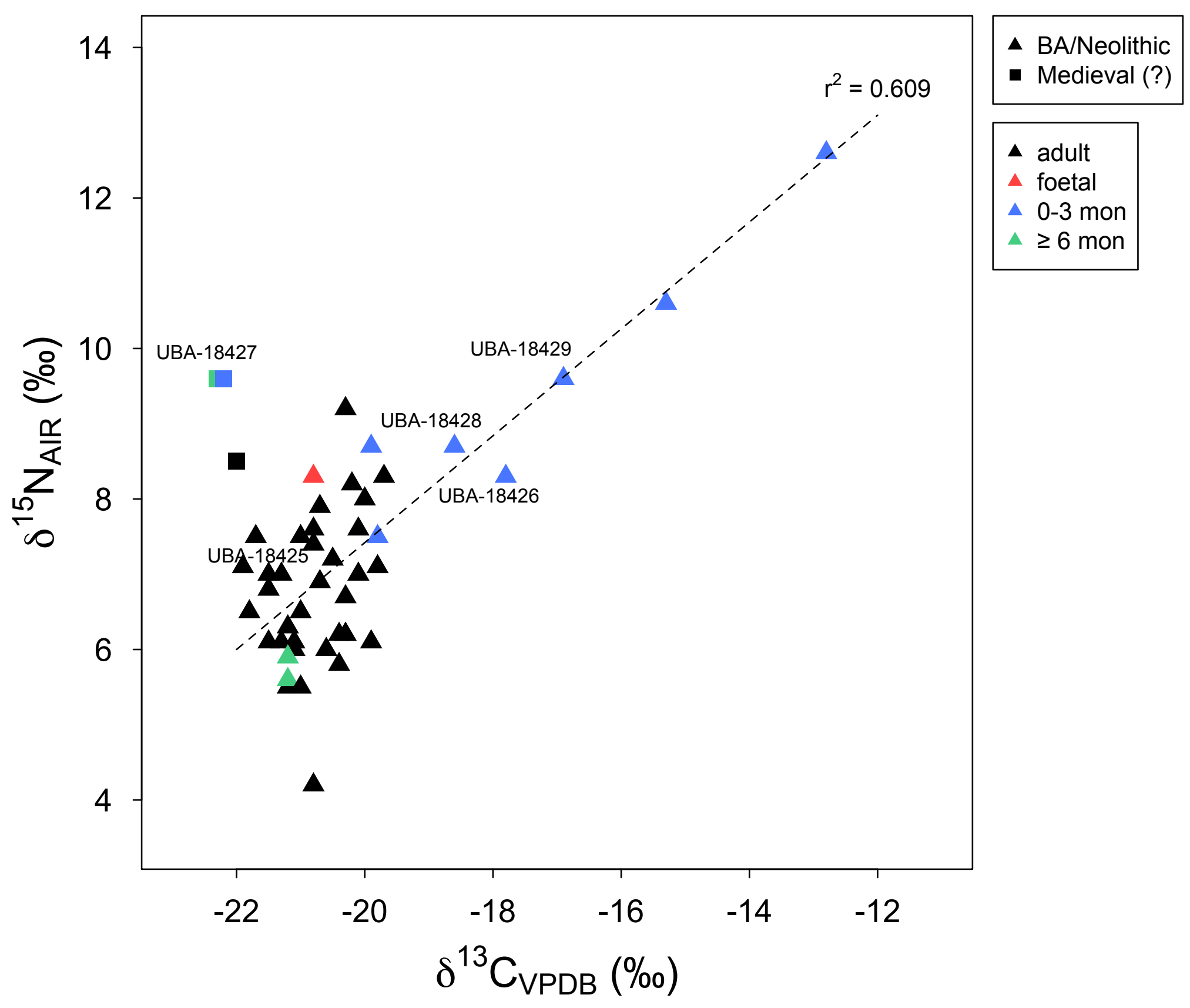




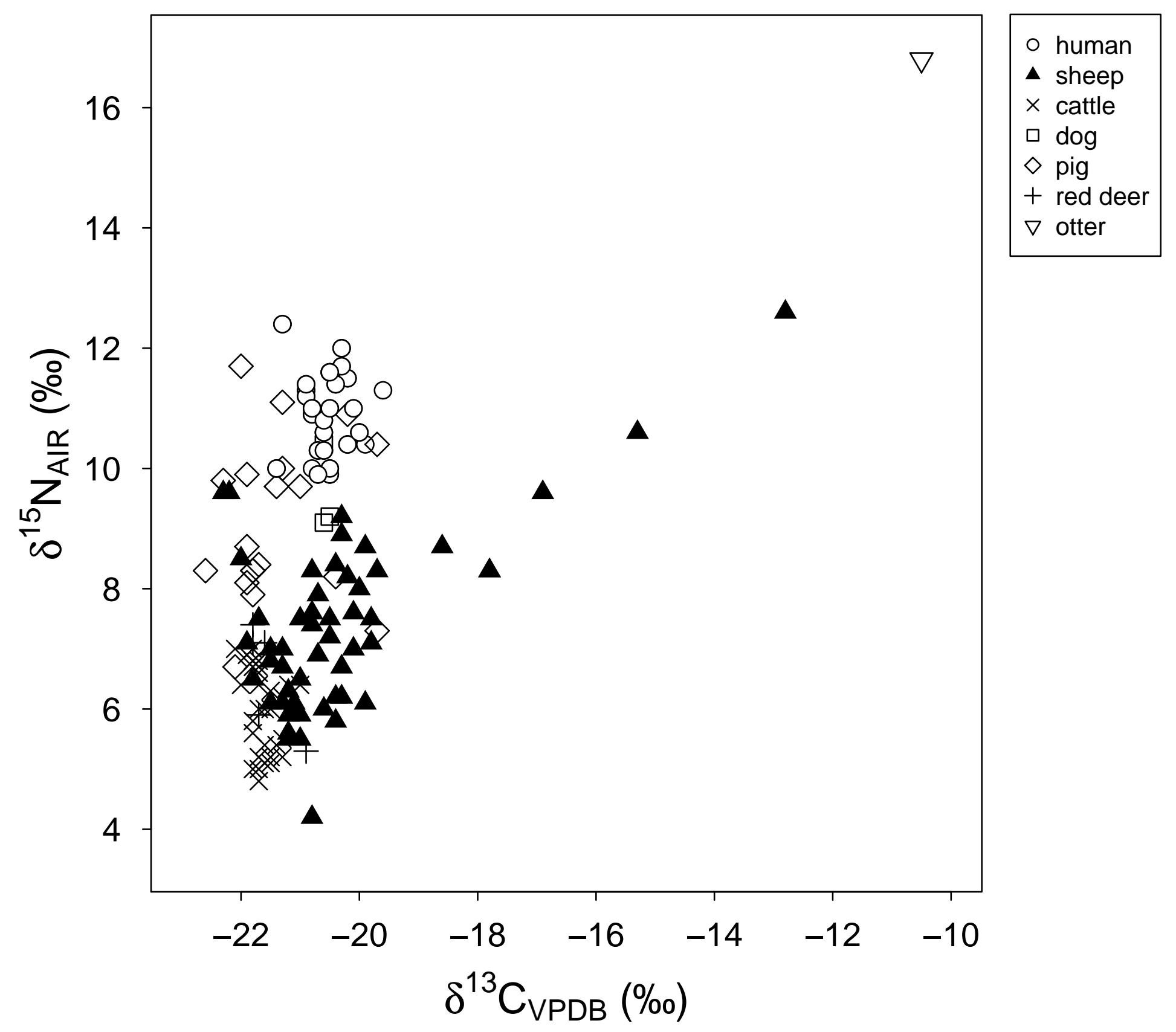




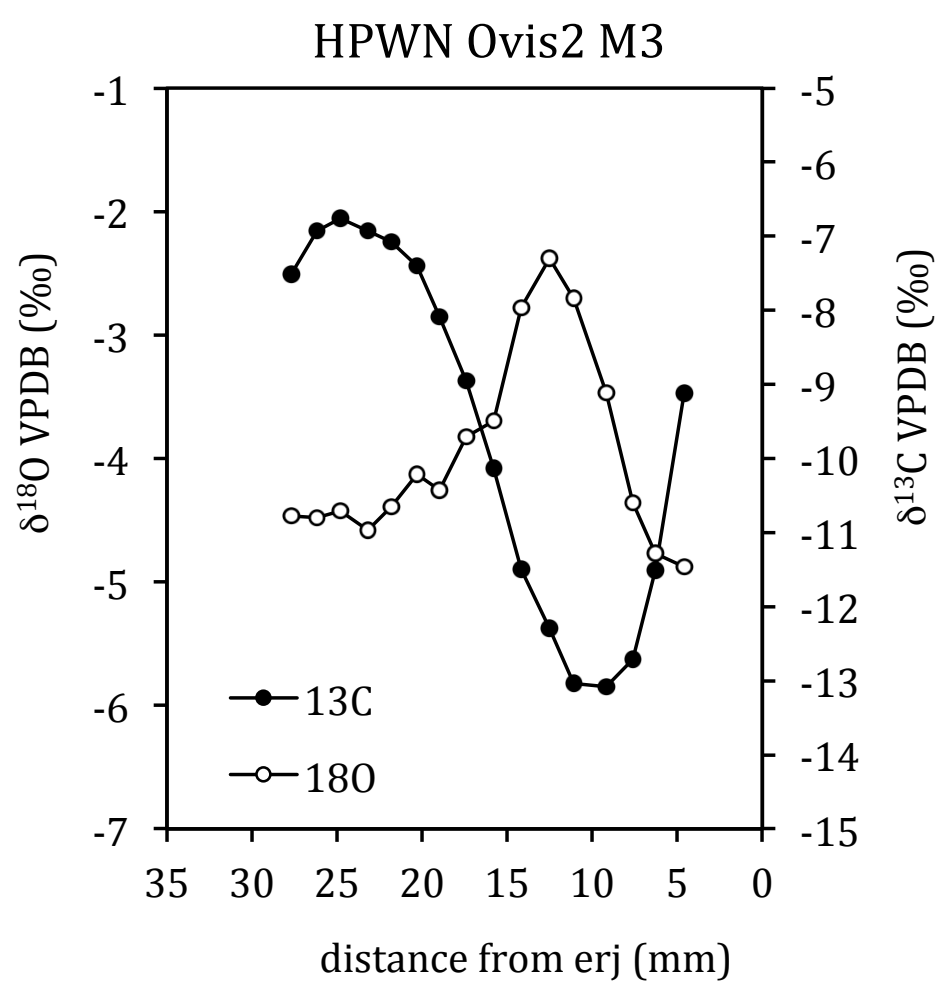

Figure 6a

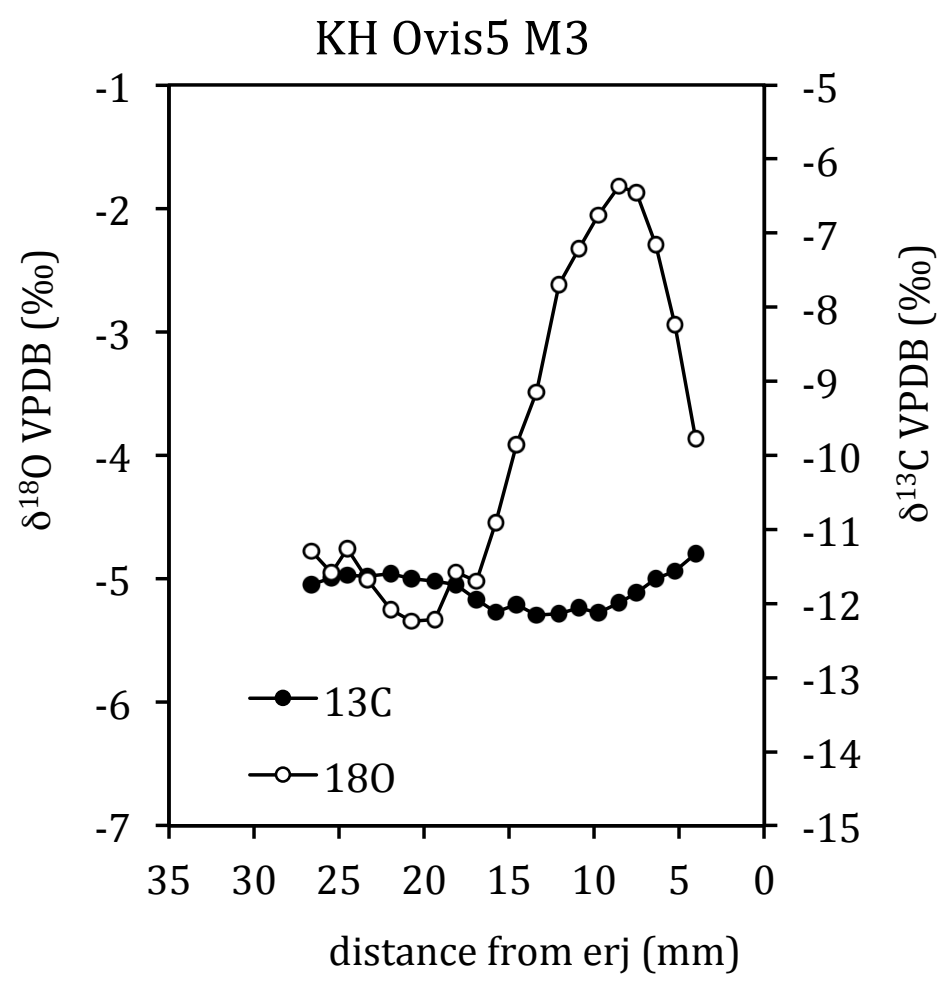

Figure $6 b$ 